\title{
HUBUNGAN KAUSALITAS INVESTASI DENGAN PERTUMBUHAN EKONOMI INDONESIA
}

\author{
Fitri Amalia \\ Asosiasi Dosen Indonesia \\ v3@gmail.com
}

\begin{abstract}
.
This research aim to know how the relation of causality between investment, in this case governmental investment and investment of private sector with growth of Indonesia. Data applied is data time series during 36 years and is secondary data. There are some variable applied in this research, that is: growth of chartered investment counsel proxy with value GDP, investment of government proxy with disbursement of government, investment of foreign private sector (PMA) and investment of domestic private sector (PMDN). Method applied analyst to the relation of causality is with approach of model Vector Auto Regression (VAR). To test there are no of the relation of causal between variable is applied [by] causality test Granger. Result of testing of Granger indicates that there are three the relation of concurrent. Based on the result, hence chartered gross domestic product (GDP), governmental investment and investment of domestic private sector (PMDN) in significant influences investment of foreign private sector (PMA) and not happened on the contrary.
\end{abstract}

Keywords: Investment; Vector Auto Regression; Granger Causality

\begin{abstract}
Abstrak.
Penelitian ini bertujuan untuk mengetahui bagaimana hubungan kausalitas antara investasi, dalam hal ini investasi pemerintah dan investasi dari sektor swasta dengan pertumbuhan ekonomi Indonesia. Data yang digunakan adalah data time series selama 36 tahun. Ada beberapa variabel yang digunakan dalam penelitian ini, yaitu: pertumbuhan investasi proksi dengan nilai GDP, investasi proxy pemerintah dengan pengeluaran pemerintah, investasi swasta asing (PMA) dan investasi dari sektor swasta dalam negeri (PMDN). Metode analisis yang digunakan pada hubungan kausalitas adalah dengan pendekatan model Vector Auto Regression (VAR). Untuk menguji ada tidaknya hubungan kausal antara variabel digunakan uji kausalitas Granger. Hasil pengujian Granger menunjukkan bahwa terdapat tiga hubungan bersamaan. Berdasarkan hasil tersebut, pertumbuhan (PDB), investasi pemerintah dan investasi sektor swasta secara signifikan mempengaruhi sektor swasta asing (PMA) dan tidak terjadi sebaliknya.
\end{abstract}

Kata Kunci: Investasi; Vector Auto Regression; Kausalitas Granger

Diterima: 30 Oktober 2012; Direvisi: 2 Januari 2013; Disetujui: 8 Januari 2013 


\section{PENDAHULUAN}

Peningkatan investasi akan memberikan pengaruh bagi pertumbuhan ekonomi di suatu negara. Ada beberapa studi literatur yang melihat hubungan antara berbagai indikator ekonomi. Menurut Harrod-Domar (1948) yang dikutip oleh Falianty (2006), investasi sangat penting terhadap pertumbuhan ekonomi. Investasi akan meningkatkan stok barang modal yang memungkinkan mendorong output. Borensztein, et.al (1998) mengestimasi dampak FDI terhadap pertumbuhan ekonomi di 69 negara berkembang selama periode 1970-1989 yang menunjukkan bahwa FDI berpengaruh positif terhadap pertumbuhan ekonomi. Sedangkan menurut Kojima (1978) FDI bersifat komplemen dan mendukung pembangunan di negara penerima FDI. Semakin besar investasi asing langsung yang masuk ke dalam suatu negara maka semakin tinggi pula pertumbuhan ekonomi yang dapat dicapai oleh negara tersebut. Begitupun dengan penelitian lainnya (Erdal dan Totulu, 2002; Ito, 1999) yang masing-masing menunjukkan hubungan positif dan signifikan antara FDI dengan pertumbuhan GDP riil atau pertumbuhan ekonomi di Turki dan di negaranegara Asia. Di samping investasi swasta asing dalam bentuk FDI, investasi swasta domestik juga memberikan pengaruh bagi pertumbuhan ekonomi (Sinha, 1999).

Namun demikian, pertumbuhan ekonomi yang tinggi dapat pula mendorong terjadinya peningkatan investasi. Dalam teori ekonomi pembangunan diketahui bahwa tingkat pertumbuhan ekonomi dan investasi mempunyai hubungan timbal balik yang positif. Hubungan timbal balik tersebut terjadi karena di satu pihak, semakin tinggi pertumbuhan ekonomi suatu negara berarti semakin besar bagian dari pendapatan yang bisa ditabung, sehingga investasi yang tercipta akan semakin besar pula. Sementara itu arah hubungan pertumbuhan terhadap investasi dapat di jelaskan pula melalui konsumsi. Kenaikan pendapatan menyebabkan konsumsi atau daya beli masyarakat meningkat sehingga permintaan barang dan jasa meningkat pula. Peningkatan permintaan tersebut mendorong kebutuhan investasi yang semakin besar. Dalam kasus ini investasi merupakan fungsi dari pertumbuhan ekonomi.

Konsep hubungan kausalitas yang terjadi antara investasi dan pertumbuhan dapat di jelaskan melalui proses akselerasi. Menurut asas akselerasi maka investasi pada saat ini akan meningkatkan kemampuan berproduksi dan menambah pendapatan di masa datang. Kenaikan pendapatan di periode mendatang melalui asas akselerasi 
juga akan meningkatkan investasi yang akan dilakukan pada periode yang bersangkutan. Hal tersebut didukung pula oleh penelitian Chowdury dan Mavrotas (2005) yang menunjukkan adanya hubungan kausalitas (dua arah) antara FDI sebagai bentuk investasi asing terhadap pertumbuhan di Malaysia dan Thailand.

Pengeluaran pemerintah sebagai suatu bentuk investasi pemerintah memiliki kedudukan yang cukup penting dalam meningkatkan laju pertumbuhan ekonomi negara. Menurut Samuelson dan Nordhaus (1992) apabila pengeluaran pembangunan bertambah tinggi maka pengeluaran agregat pun bertambah tinggi dan selanjutnya tingkat kegiatan ekonomi menjadi bertambah tinggi pula begitupun sebaliknya.

Beberapa peneliti mengemukakan bahwa pengaruh yang timbul dari adanya perubahan pengeluaran pemerintah terhadap kegiatan ekonomi ada dua hal: Pertama, pengeluaran pemerintah akan mengakibatkan peningkatan pada pendapatan masyarakat, peningkatan pendapatan masyarakat ini akan meningkatkan daya beli sehingga menguntungkan pihak swasta dan mendorong kenaikan investasi. Kenaikan investasi akan meningkatkan kegiatan ekonomi. Kedua, peningkatan pengeluaran pemerintah pada awalnya akan meningkatkan permintaan agregat dan pendapatan. Tetapi hal tersebut akan segera disusul oleh kenaikan permintaan akan uang. Dengan jumlah uang yang beredar tidak berubah, suku bunga akan melonjak untuk menyesuaikan pasar uang. Pada saat suku bunga naik akibat adanya kelebihan permintaan uang, maka pengeluaran investasi akan segera menurun.

Pengeluaran pembangunan sebagai bentuk dari investasi pemerintah memiliki kaitan langsung serta memberikan dampak positif terhadap pelaksanaan pembangunan. Hal tersebut diperkuat oleh penelitian Sala-i-Martin (2003) dan Lachler (1998), masingmasing di negara Arab dan Meksiko yang memberi kesimpulan bahwa terdapat pengaruh positif investasi, terutama investasi publik terhadap pertumbuhan ekonomi. Verma dan Wilson (2005) melakukan penelitian di India dengan hasil serupa bahwa investasi publik secara signifikan berdampak pada output atau GDP. Sementara hasil yang berbeda di temukan di Indonesia melalui penelitian Yonathan, dimana pertumbuhan yang dicapai selama periode 1983/1984 hingga 1999/2000 bukan 
dikarenakan investasi, dalam hal ini investasi pemerintah, melainkan lebih disebabkan karena adanya faktor konsumsi.

Investasi pemerintah dapat pula mendorong atau mempengaruhi investasi swasta baik secara langsung atau pun tidak. Hal tersebut seperti yang dinyatakan oleh Aschauer (1989) mengenai hubungan antara modal publik dan swasta. Akumulasi modal publik yang tinggi akan meningkatkan tingkat investasi nasional dan mendorong terciptanya crowding out terhadap investasi swasta. Meningkatnya cadangan modal publik juga meningkatkan pengembalian pada modal swasta. Dengan demikian, baik investasi publik maupun swasta seharusnya dapat meningkat dan berjalan seiring agar pertumbuhan ekonomi dapat meningkat pula. Beberapa penelitian empiris menjelaskan hal tersebut, diantaranya: Sala-i-Martin (2003), Borensztein Et al (1995), Sinha (1999), Lachler (1998) serta Kweka dan Morrissey (2000) yang menyimpulkan bahwa investasi memiliki pengaruh positif bagi pertumbuhan ekonomi.

Berdasarkan uraian pada latar belakang masalah di atas, maka masalah pokok penelitian dapat di rumuskan sebagai berikut: "Bagaimana hubungan kausalitas antara investasi dengan pertumbuhan ekonomi Indonesia?". Secara spesifik, identifikasi masalah dalam penelitian ini meliputi:

- Bagaimana hubungan kausalitas antara investasi pemerintah dengan pertumbuhan ekonomi Indonesia?

- Bagaimana hubungan kausalitas antara investasi swasta asing dengan pertumbuhan ekonomi Indonesia?

- Bagaimana hubungan kausalitas antara investasi swasta domestik dengan pertumbuhan ekonomi Indonesia?

- Bagaimana hubungan di antara investasi pemerintah, investasi swasta asing dan investasi swasta domestik di Indonesia?

\section{Teori Keynes (Teori Multiplier)}

Teori Keynes sangat mementingkan sisi permintaan agregat. Dalam pandangan Keynes, pendapatan total tergantung dari permintaan efektif yang terdiri dari permintaan konsumsi dan permintaan investasi. Permintaan efektif inilah yang menentukan tingkat keseimbangan. Ketika terjadi ketidakseimbangan antara konsumsi dan pendapatan, menurut Keynes dapat dijembatani oleh investasi, dengan 
meningkatkan investasi maka akan mengakibatkan naiknya pendapatan, hal ini terjadi karena adanya efek multiplier (pengganda).

Teori ini merupakan teori ekonomi makro yang digunakan untuk menjelaskan bagaimana output ditentukan dalam jangka pendek, artinya bahwa pada setiap perubahan satu dollar pada pengeluaran eksogen (seperti investasi) menyebabkan perubahan lebih dari satu dollar (atau perubahan berganda) pada GDP. Keynes mendasarkan analisa multiplier pada konsep yang menyangkut kecenderungan konsumsi dan berasumsi bahwa harga-harga dan upah selalu stabil. Investasi dapat didorong melalui peningkatan efisiensi dari modal atau penurunan suku bunga. Kenaikan investasi menyebabkan naiknya pendapatan yang kemudian akan meningkatkan konsumsi, sementara peningkatan konsumsi pada akhirnya akan menaikkan tingkat kesejahteraan.

\section{Teori Harrod-Domar}

Teori Harrod-Domar pada dasarnya merupakan pengembangan dari teori makro Keynes jangka pendek menjadi suatu teori makroekonomi jangka panjang. Aspek utama yang dikembangkan dari teori Keynes adalah aspek yang menyangkut peranan investasi (I) dalam jangka pendek. Dalam teori Keynes, pengeluaran investasi (I) mempengaruhi permintaan agregat (AD) tetapi tidak mempengaruhi penawaran agregat (AS). Harrod-Domar melihat pengaruh investasi (I) dalam jangka waktu yang lebih panjang. Menurut keduanya, pengeluaran investasi tidak hanya mempunyai pengaruh (melalui proses multiplier) terhadap permintaan agregat, tetapi juga terhadap penawaran agregat melalui pengaruhnya terhadap kapasitas produksi.

Menurut teori pertumbuhan Harrod-Domar, dalam suatu proses pertumbuhan terdapat ketidakseimbangan atau ketidakstabilan (instability theorem) yang dapat mengganggu kondisi ekuilibrium, sehingga diperlukan adanya campur tangan atau intervensi dari negara melalui kebijakan yang dibuatnya. Menurutnya ada pesyaratan yang harus dipenuhi untuk memelihara ekuilibrium antara tabungan- investasi- pendapatan. Gagasan Domar berpangkal tolak pada berlakunya asas investment multiplier, sedangkan dalam analisis Harrod lebih menekankan pada peran asas acceleration, namun keduanya tetap menempatkan capital output ratio (COR) sebagai hal yang paling penting. Menurut asas akselerasi, pertumbuhan output yang cepat dapat merangsang investasi, dan sebaliknya, investasi yang tinggi merangsang pertumbuhan 
output lebih besar, dan proses akan berlanjut hingga kapasitas ekonomi telah tercapai, yaitu titik dimana laju pertumbuhan ekonomi mulai melambat. Pertumbuhan yang lebih pelan dapat mengurangi pengeluaran investasi dan akumulasi inventaris, sehingga cenderung menyebabkan ekonomi mengalami resesi.

Menurut Harrod, berdasarkan asas akselerasi maka investasi pada saat ini akan meningkatkan kemampuan berproduksi dan menambah pendapatan di masa datang. Kenaikan pendapatan di periode mendatang melalui asas akselerasi juga akan meningkatkan investasi yang akan dilakukan pada periode yang bersangkutan.

\section{Investasi dan Pertumbuhan Ekonomi}

Terdapat beberapa penelitian empiris yang menunjukkan adanya hubungan positif antara investasi terhadap pertumbuhan diantaranya Borensztein (1995), Falianty (2006), Feridun (2006) yang menunjukkan adanya pengaruh antara investasi swasta asing (FDI) terhadap pertumbuhan ekonomi. Begitupun dengan penelitian lainnya (Erdal dan Totulu, 2002; Ito, 1999) yang masing-masing menunjukkan hubungan positif dan signifikan antara FDI dengan pertumbuhan GDP riil atau pertumbuhan ekonomi di Turki dan di negara-negara Asia. Di samping investasi swasta asing dalam bentuk FDI, investasi swasta domestik juga memberikan pengaruh bagi pertumbuhan ekonomi (Sinha, 1999). Pengaruh investasi swasta tidak selamanya positif terhadap pertumbuhan. Terkadang bagi suatu negara justru investasi swasta akan menimbulkan dampak negatif bagi pertumbuhan (Kweka, 2000). Berdasarkan beberapa penelitian tersebut dapat disimpulkan bahwa pertumbuhan merupakan fungsi dari investasi.

\section{Investasi Pemerintah dan Investasi Swasta}

Investasi pemerintah dapat mendorong atau mempengaruhi investasi swasta baik secara langsung ataupun tidak. Hal tersebut seperti yang dinyatakan oleh Aschauer (1989) mengenai hubungan antara modal publik dan swasta. Akumulasi modal publik yang tinggi akan meningkatkan tingkat investasi nasional dan mendorong terciptanya crowding out terhadap investasi swasta. Meningkatnya cadangan modal publik juga meningkatkan pengembalian pada modal swasta. Investasi pemerintah dapat pula mempengaruhi pertumbuhan ekonomi dan memberi efek bagi investasi swasta melalui peningkatan output (Lachler, 1998, Sala-i-Martin, 2003, Verma, 2005). Ketika suatu negara atau daerah memiliki sarana dan fasilitas publik yang baik 
melalui investasi yang dilakukan oleh pemerintah, maka pihak swasta pun akan tertarik untuk berinvestasi di negara tersebut. Begitu pula di dalam penyediaan infrastruktur dan barang publik lainnya. Semakin baik infrastruktur maka semakin banyak pula investor swasta yang ingin melakukan investasi (Ford, 2005, Goodspeed, 2006).

\section{Kerangka Pemikiran}

Dalam teori ekonomi pembangunan diketahui bahwa tingkat pertumbuhan ekonomi dan investasi mempunyai hubungan timbal balik yang positif. Pertumbuhan ekonomi yang tinggi menyebabkan terjadinya kenaikan pendapatan, baik pendapatan nasional maupun pendapatan perkapita. Sesuai fungsi identitas, dimana $\mathrm{Y}=\mathrm{C}+\mathrm{S}$ dan $\mathrm{Y}=\mathrm{C}+\mathrm{I}$ maka kenaikan pendapatan akan berdampak pada peningkatan konsumsi dan tabungan. Dan selama pertumbuhan tumbuh secara positif, maka konsumsi dan tabungan akan meningkat atau tumbuh secara bersama-sama. Apabila diasumsikan pertumbuhan positif, maka semakin tinggi pertumbuhan ekonomi suatu negara berarti semakin besar bagian dari pendapatan yang bisa ditabung, sehingga investasi yang tercipta akan semakin besar pula. Sementara itu arah hubungan pertumbuhan terhadap investasi dapat dijelaskan pula melalui konsumsi. Kenaikan pendapatan menyebabkan konsumsi atau daya beli masyarakat meningkat sehingga permintaan barang dan jasa meningkat pula. Peningkatan permintaan tersebut mendorong kebutuhan investasi yang semakin besar. Dalam kasus ini investasi merupakan fungsi dari pertumbuhan ekonomi.

Konsep hubungan kausalitas yang terjadi antara investasi dan pertumbuhan dapat di jelaskan melalui proses akselerasi. Menurut asas akselerasi maka investasi pada saat ini akan meningkatkan kemampuan berproduksi dan menambah pendapatan di masa datang. Kenaikan pendapatan di periode mendatang melalui asas akselerasi juga akan meningkatkan investasi yang akan dilakukan pada periode yang bersangkutan.

Sementara itu, hubungan kausalitas antara investasi pemerintah dan pertumbuhan ekonomi dapat dijelaskan sebagai berikut: Infrastruktur, sebagai salah satu bentuk investasi pemerintah dan pendapatan (pendapatan perkapita) sebagai bagian dari pertumbuhan ekonomi memiliki korelasi positif. Hal ini menunjukkan bahwa 
infrastruktur yang baik akan merangsang peningkatan pendapatan masyarakatnya. Karena aktivitas perekonomian meningkat sebagai akibat mobilitas faktor produksi dan aktivitas perdagangan yang semakin tinggi. Korelasi positif antar kedua variabel itu juga bisa berarti semakin tinggi pendapatan perkapita maka akan semakin memiliki kemampuan menyediakan infrastruktur karena kemampuan membayar pajak lebih tinggi dan daya beli yang meningkat.

Pengaruh atau hubungan antara perubahan pengeluaran pemerintah terhadap kegiatan ekonomi dapat pula dijelaskan sebagai berikut: Pertama, pengeluaran pemerintah akan mengakibatkan peningkatan pada pendapatan masyarakat, peningkatan pendapatan masyarakat ini akan meningkatkan daya beli sehingga menguntungkan pihak swasta dan mendorong kenaikan investasi. Kenaikan investasi akan meningkatkan kegiatan ekonomi. Kedua, peningkatan pengeluaran pemerintah pada awalnya akan meningkatkan permintaan agregat dan pendapatan. Tetapi hal tersebut akan segera disusul oleh kenaikan permintaan akan uang. Dengan jumlah uang yang beredar tidak berubah, suku bunga akan melonjak untuk menyesuaikan pasar uang. Pada saat suku bunga naik akibat adanya kelebihan permintaan uang, maka pengeluaran investasi akan segera menurun. Investasi pemerintah tersebut menimbulkan suatu dampak atau efek yang dikenal dengan istilah crowding out effect maupun crowding in effect.

Investasi pemerintah dapat mempengaruhi pertumbuhan ekonomi dan memberi efek bagi investasi swasta melalui peningkatan output. Ketika suatu negara atau daerah memiliki sarana dan fasilitas publik yang baik melalui investasi yang dilakukan oleh pemerintah, maka pihak swasta pun akan tertarik untuk berinvestasi di negara tersebut. Begitu pula di dalam penyediaan infrastruktur dan barang publik lainnya. Semakin baik infrastruktur maka semakin banyak pula investor swasta yang ingin melakukan investasi. Semakin besar investasi, maka modal yang dihasilkan semakin besar yang berarti output yang dihasilkan akan semakin besar pula. Karena output yang tersedia dalam jumlah besar akan dapat mendorong tercapainya pertumbuhan ekonomi yang tinggi.

\section{METODE}

Dalam penelitian ini yang menjadi objek penelitian meliputi investasi dan pertumbuhan ekonomi. Pertumbuhan ekonomi di tunjukkan dengan kenaikan produk domestik bruto (Gross Domestic Product) pada setiap tahun. Sedangkan untuk investasi dibagi 
menjadi tiga, yaitu: investasi pemerintah, investasi swasta asing serta investasi swasta domestik. Sedangkan jenis data yang digunakan merupakan data sekunder yang diperoleh melalui penelitian kepustakaan (library research) ke berbagai sumber dan instansi yang terkait. Penelitian ini terdiri dari 4 (empat) variabel, yaitu: pertumbuhan ekonomi, investasi pemerintah, investasi swasta asing dan investasi swasta domestik. Masing-masing variabel diproksi melalui nilai tertentu dengan skala rasio seperti di tunjukkan pada tabel berikut:

Tabel 1. Operasionalisasi Variabel

\begin{tabular}{|c|c|c|}
\hline Variabel & Definisi & Skala \\
\hline $\begin{array}{l}\text { Pertumbuhan } \\
\text { Ekonomi (y) }\end{array}$ & $\begin{array}{l}\text { Pertumbuhan atau kenaikan output dalam jangka panjang. } \\
\text { Pertumbuhan ekonomi merupakan selisih antara output } \\
\text { tahun tertentu dengan tahun sebelumnya (dy/y) }\end{array}$ & Rasio \\
\hline Output (GDP) & $\begin{array}{l}\text { Nilai produk yang dihasilkan suatu negara dalam jangka } \\
\text { waktu satu tahun. Untuk melihat output suatu negara dapat } \\
\text { dilihat dari nilai Produk Domestik Bruto (Gross Domestic } \\
\text { Product, GDP) }\end{array}$ & Rasio \\
\hline $\begin{array}{l}\text { Investasi } \\
\text { Pemerintah } \\
\text { (IP) }\end{array}$ & $\begin{array}{l}\text { Investasi atau penanaman modal yang dilakukan oleh } \\
\text { pemerintah. Data mengenai investasi ini dapat dilihat dari } \\
\text { besarnya realisasi total pengeluaran atau belanja } \\
\text { pemerintah. }\end{array}$ & Rasio \\
\hline $\begin{array}{l}\text { Investasi } \\
\text { Swasta Asing } \\
\text { (ISA) }\end{array}$ & $\begin{array}{l}\text { Investasi atau penanaman modal yang dilakukan oleh } \\
\text { pihak swasta asing atau luar negeri. Data mengenai } \\
\text { investasi ini dapat dilihat dari besarnya nilai penanaman } \\
\text { modal asing (PMA). }\end{array}$ & Rasio \\
\hline $\begin{array}{l}\text { Investasi } \\
\text { Swasta } \\
\text { Domestik } \\
\text { (ISD) }\end{array}$ & $\begin{array}{l}\text { Investasi atau penanaman modal yang dilakukan oleh } \\
\text { pihak swasta domestik atau dalam negeri. Data mengenai } \\
\text { investasi ini dapat dilihat dari besarnya nilai penanaman } \\
\text { modal dalam negeri (PMDN). }\end{array}$ & Rasio \\
\hline
\end{tabular}

Metode yang digunakan untuk menganalisis hubungan kausal antara variabel-variabel yang menjadi objek penelitian ini adalah analisis kuantitatif dengan menggunakan model vector autoregression (VAR). Model ini dipilih karena VAR merupakan alat analisis yang sangat berguna, baik dalam memahami adanya hubungan timbal balik (interrelationship) antara variabel-variabel ekonomi, maupun di dalam pembentukan model ekonomi berstruktur.

Di dalam metode VAR ini ada beberapa pengujian yang dilakukan. Pengujian pertama adalah uji akar unit (uji stasioner). Kemudian diikuti dengan pengujian lainnya diantaranya penentuan panjang lag, estimasi VAR, uji kointegrasi, uji kausalitas Granger, impuls respon serta analisis dekomposisi varians. 
Model VAR dibangun dengan memperlakukan keempat variabel yaitu produk domestik bruto (Gross Domestic Product), investasi pemerintah, investasi swasta asing dan investasi swasta domestik sebagai variabel endogen dan menyertakan nilai lag masing-masing variabel di sisi kanan persamaan. Jika ditulis dalam bentu matriks, maka bentuknya adalah sebagai berikut ini:

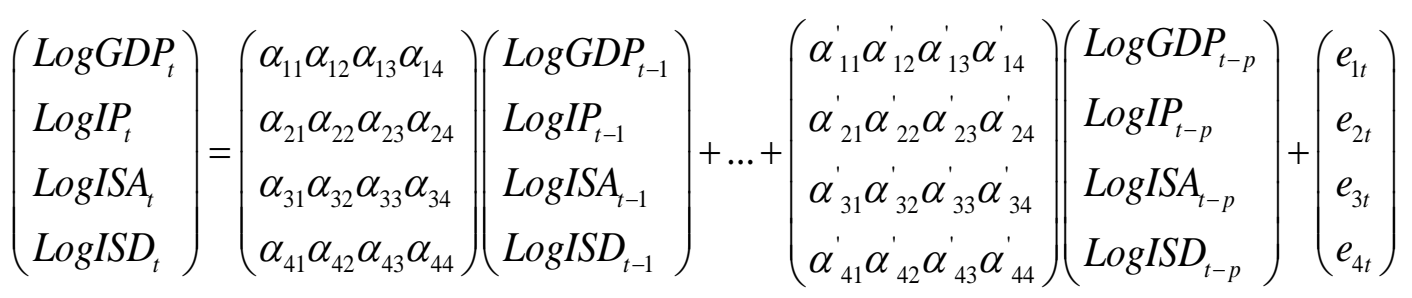

Apabila bentuk matrik di atas diubah ke dalam suatu persamaan, maka model persamaannya adalah sebagai berikut:

$$
\begin{aligned}
& \log G D P_{t}=\alpha_{10}+\sum_{i=1}^{p} \alpha_{11}(i) \log G D P_{t-i}+\sum_{i=1}^{p} \alpha_{12}(i) \log I P_{t-i}+\sum_{i=1}^{p} \alpha_{13}(i) \log I S A_{t-i}+\sum_{i=1}^{p} \alpha_{14}(i) \log I S D_{t-i}+\varepsilon_{1 t} \\
& \operatorname{LogIP} P_{t}=\alpha_{20}+\sum_{i=1}^{p} \alpha_{21}(i) \log G D P_{t-i}+\sum_{i=1}^{p} \alpha_{22}(i) \log I P_{t-i}+\sum_{i=1}^{p} \alpha_{23}(i) \operatorname{LogISA}_{t-i}+\sum_{i=1}^{p} \alpha_{24}(i) \log I S D_{t-i}+\varepsilon_{2 t}
\end{aligned}
$$

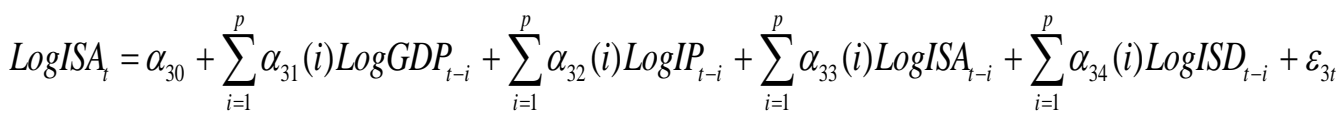

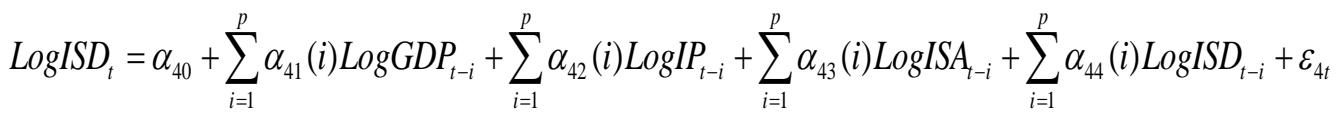

Keterangan:

GDP = Gross Domestic Product, merupakan proksi dari pertumbuhan ekonomi

$\mathrm{IP} \quad=$ Investasi Pemerintah (diproksi dengan pengeluaran pemerintah)

ISA = Investasi Swasta Asing (diproksi dengan Penanaman Modal Asing, PMA)

ISD = Investasi Swasta Domestik (diproksi dengan Penanaman Modal Dalam Negeri, PMDN)

$\varepsilon \quad=$ error term 


\section{HASIL DAN PEMBAHASAN}

Berdasarkan hasil uji akar unit dengan menggunakan analisis Augmented Dicky-Fuller terhadap variabel yang diamati, maka semua data dari setiap variabel tidak stasioner pada level sementara pada tingkat level (first difference) semua data stasioner. Hasil estimasi VAR menunjukkan bahwa pada lag 1 hampir semua variabel bebas mempunyai pengaruh secara signifikan terhadap variabel terikat. Berdasarkan hasil uji kointegrasi Johansen dapat diketahui bahwa pada lag 1 terdapat empat persamaan yang terkointegrasi pada taraf nyata $5 \%$ atau tingkat kepercayaan 95\%. Dengan demikian, maka pada lag 1 variabel-variabel dalam model terkointegrasi atau dengan kata lain memiliki keseimbangan hubungan jangka panjang.

Sementara itu hasil pengujian kausalitas Granger menunjukkan bahwa hubungan antara variabel tidak saling mempengaruhi (dua arah) pada tingkat signifikan ( $\alpha=5 \%$ ). Hanya terdapat tiga hubungan searah, yaitu hubungan antara pertumbuhan ekonomi terhadap investasi asing, hubungan antara investasi pemerintah terhadap investasi asing serta hubungan antara investasi domestik terhadap investasi asing. Sementara untuk hubungan antara suatu variabel terhadap variabel lainnya tidak memiliki pengaruh secara signifikan. Hal tersebut ditunjukkan dari nilai probabilitas yang lebih besar dari taraf signifikansi $1 \%, 5 \%$ maupun $10 \%$.

Berdasarkan hasil tersebut, maka hanya pertumbuhan ekonomi, investasi pemerintah serta investasi swasta domestik yang secara signifikan mempengaruhi investasi swasta asing, dan tidak terjadi sebaliknya. Dengan demikian dapat dikatakan bahwa investasi asing yang masuk ke Indonesia masih sangat dipengaruhi oleh kondisi perekonomian negara Indonesia serta oleh kegiatan investasi setempat, baik yang dilakukan oleh pemerintah sendiri maupun oleh investor lokal atau dalam negeri.

Hubungan yang terjadi antara pertumbuhan ekonomi dengan investasi swasta asing terjadi searah, dimana hanya pertumbuhan ekonomi yang mempengaruhi investasi swasta asing. Hal ini dapat terjadi karena kenaikan pada gross domestic product sebelumnya akan meningkatkan jumlah dan nilai investasi asing yang masuk ke Indonesia. Jadi pada dasarnya para investor asing yang akan menanamkan modalnya pada tahun ini akan melihat posisi GDP pada tahun sebelumnya, karena dengan 
melihat nilai GDP paling tidak dapat mencerminkan kondisi perekonomian suatu negara.

Tabel 2. Hasil Perhitungan Granger Causality Test; Lag 1

\begin{tabular}{lccc}
\hline \hline Null Hypothesis: & Obs & F-Statistic & Probability \\
\hline \hline LIP does not Granger Cause LGDP & \multirow{2}{*}{35} & 0.10054 & 0.75324 \\
LGDP does not Granger Cause LIP & & 2.38642 & 0.13223 \\
\hline \hline LISA does not Granger Cause LGDP & \multirow{2}{*}{35} & 0.31359 & 0.57939 \\
LGDP does not Granger Cause LISA & & 10.0074 & 0.00341 \\
\hline \hline LISD does not Granger Cause LGDP & \multirow{2}{*}{35} & 2.17825 & 0.14975 \\
LGDP does not Granger Cause LISD & & 0.89608 & 0.35093 \\
\hline \hline LISA does not Granger Cause LIP & \multirow{2}{*}{35} & 1.48009 & 0.23266 \\
LIP does not Granger Cause LISA & & 5.38892 & 0.02679 \\
\hline \hline LISD does not Granger Cause LIP & \multirow{2}{*}{35} & 0.53194 & 0.47110 \\
LIP does not Granger Cause LISD & & 2.54678 & 0.12035 \\
\hline \hline LISD does not Granger Cause LISA & \multirow{2}{*}{35} & 6.44373 & 0.01620 \\
LISA does not Granger Cause LISD & & 0.31938 & 0.57592 \\
\hline \hline
\end{tabular}

Investasi pemerintah secara signifikan mempengaruhi investasi asing. Para investor asing masih melihat peran pemerintah suatu negara (Indonesia) terutama dalam menyediakan infrastruktur serta fasilitas publik. Semakin tersedianya infrastruktur serta fasilitas publik tersebut, baik dari segi kualitas maupun kuantitas, akan mendorong investor asing dalam berinvestasi di Indonesia. Sebab salah satu penarik bagi investor asing untuk menanamkan modalnya adalah tersedianya infrastruktur yang memadai yang akan memperlancar aktivitas produksi maupun distribusi. Namun pengadaan infrastruktur memerlukan jeda waktu (time lag) sebelum dapat digunakan sepenuhnya.

Oleh karenanya investasi yang dilakukan pemerintah pada suatu waktu tidak dapat dirasakan pada saat itu juga. Sementara itu, hubungan antara investasi domestik dan investasi asing secara signifikan bersifat searah. Investasi asing tahun ini dipengaruhi oleh investasi domestik tahun lalu atau dengan kata lain besarnya investasi domestik di tahun ini akan mempengaruhi investasi asing yang dilakukan tahun depan. Output produksi dari investasi domestik dapat mendorong investor asing untuk meningkatkan output dari produksi yang serupa maupun 
meningkatkan produksi yang dapat melengkapi output yang dihasilkan perusahaan dalam negeri (bersifat komplementer).

\section{SIMPULAN}

Secara umum hubungan kausalitas yang terjadi antara investasi dengan pertumbuhan ekonomi di Indonesia bersifat searah. Pertumbuhan ekonomi secara signifikan mempengaruhi investasi, dan secara signifikan tidak terjadi sebaliknya. Investasi sebagai salah satu komponen pengeluaran agregat belum mampu meningkatkan atau mendorong tercapainya pertumbuhan ekonomi seperti yang diharapkan.

Berdasarkan hasil uji kausalitas, diketahui bahwa secara signifikan tidak terdapat hubungan kausalitas antara investasi pemerintah dengan pertumbuhan ekonomi. Hal ini dapat saja dikarenakan investasi yang dilakukan oleh sektor pemerintah lebih banyak ditujukan untuk penyediaan sarana dan prasarana publik untuk mendorong pertumbuhan sektor swasta, oleh karena itu manfaatnya belum begitu dapat dirasakan dalam jangka pendek. Pengaruh investasi pemerintah terhadap pertumbuhan ekonomi dapat dilihat dalam jangka panjang, baik pengaruhnya secara langsung maupun melalui peningkatan investasi swasta.

Pertumbuhan ekonomi secara signifikan mempengaruhi investasi swasta asing di Indonesia, sementara investasi asing tidak memiliki pengaruh yang signifikan bagi pertumbuhan ekonomi Indonesia. Disamping itu, investasi asing telah meningkatkan efisiensi investasi melalui transfer modal dan teknologi yang dapat mempengaruhi proses produksi. Dengan adanya transfer tersebut diharapkan output produksi dapat meningkat sehingga pertumbuhan ekonomi yang lebih tinggi dapat dicapai.

Berdasarkan uji kausalitas, diketahui bahwa tidak terdapat pengaruh yang signifikan antara investasi swasta domestik (PMDN) dengan pertumbuhan ekonomi. Begitupula sebaliknya, pertumbuhan ekonomi belum mampu mendorong dan meningkatkan PMDN. Dalam melakukan kegiatan investasi, para investor lokal tidak melihat tingkat pertumbuhan ekonomi yang dicapai saat ini maupun pada tahun sebelumnya. Berdasarkan hasil di atas, maka dapat disimpulkan bahwa investasi pemerintah serta investasi swasta domestik secara signifikan mempengaruhi investasi swasta asing di Indonesia. Hal ini berarti bahwa 
pada dasarnya para investor asing yang akan menanamkan modalnya pada tahun ini akan melihat posisi GDP pada tahun sebelumnya serta dengan melihat bagaimana perkembangan dan kegiatan investasi yang telah dilakukan oleh pemerintah maupun investor lokal pada tahun-tahun sebelumnya. Dengan demikian semakin meningkatnya investasi pemerintah yang ditunjukkan oleh membaiknya infrastruktur serta fasilitas publik maka akan mendorong terjadi peningkatan pada masuknya investasi asing di Indonesia.

\section{PUSTAKA ACUAN}

Atukeren, Erdal. 2004. Interactions Between Public and Private Investment: Evidence From Developing Countries. Swiss Institute for Business Cycle Research.

Barro, Robert J and Xavier Sala-i- Martin. 1995. Economic Growth. Singapore: Mc Graw-Hill International

Boediono. 1985. Teori Pertumbuhan Ekonomi. Yogyakarta: BPFE

Borensztein, Eduardo, et.al. 1995. How Does Foreign Direct Investment Affect Economic Growth. National Bureau of Economic Research. Massachusetts, Cambridge, MA. Working Paper No.5057.

Chowdury and Mavrotas. 2005. FDI and Growth: A Causal Relationship. World Institute for Development Economic Research. Research Paper No. 2005/25.

Fahmi, Irham. 2006. Analisis Investasi dalam Perspektif Ekonomi dan Politik. Bandung: PT. Refika Aditama.

Falianty, Telisa Aulia. 2006. FDI di Indonesia: Peranannya Terhadap Kinerja Makroekonomi, Masalah-masalah Yang Dihadapi dan Tantangan ke Depan. Jurnal Bisnis dan Ekonomi Politik. Vol.7. No. 2: p. 69-86.

Feridun, Mete. 2006. Impact of FDI on Economic Development: A Causality Analysis for Singapore, 1976-2002. MPRA Paper No. 1054, December 2006/ $21: 32$.

George, Ford and Thomas M. Koutsky. 2005. Broadband and Economic Development: A Municipal Case Study from Florida. Applied Economic Studies - April 2005.

Goodspeed, Timothi, et.al. 2006. Are Other Government Policies More Important than Taxation in Attracting FDI. International Studies Program. Working Paper 06-14. Georgia State University, United States of America. 
Gujarati, Damodar. 2003. Basic Econometrics, edisi keempat. New York: McGraw-Hill Higher Education.

Guritno Mangkoesoebroto. 1994. Kebijakan Ekonomi Publik di Indonesia, Substansi dan Urgensi. Jakarta: PT Gramedia Pustaka Utama Indonesia. Vol. XLIV No.2.

Hasan, Fadli. 2006. Refleksi Perbaikan Iklim Investasi: Menunggu Langkah Konkrit Pemerintah. Jurnal Bisnis dan Ekonomi Politik. Vol. 7.

Irawan dan Suparmoko. 1992. Ekonomika Pembangunan, edisi kelima. Yogyakarta: BPFE.

Jhingan, M.L. 1999. Ekonomi Pembangunan dan Perencanaan. Jakarta: PT.Raja Grafindo Persada.

Kuncoro, Mudrajad. 2003. Ekonomi Pembangunan: Teori, Masalah dan Kebijakan. Yogyakarta: UPP AMP YKPN.

Kweka, Josaphat P and Oliver Morrissey. 2000. Government Spending and Economic Growth in Tanzania, 1965-1996. Credit Research Paper, University of Nottingham, United Kingdom. No. 00/6.

Lacher, Ulrich \& David Alan Aschauer. 1998. Public Investment and Economic Growth in Mexico. The World Bank Mexico Country Department. Policy Research Working Paper 1964.

Mankiw, Gregory N. 2003. Teori Makroekonomi, edisi kelima. Jakarta: Erlangga.

Mc Eachern, William A. 2000. Ekonomi Makro. Jakarta: Salemba Empat.

Sala-i-Martin, Xavier and Elsa V. Artadi. 2003. Economic Growth and Investment in the Arab World. Colombia University, NBER and UPF and Harvard University.

Samuelson, Paul and William D.Nordhaus. 1998. Macroeconomics, sixteenth edition. Irwin McGraw-Hill.

Sinha, Dipendra. 1999. Export Instability, Investment and Economic Growth in Asia Countries: A Time Series Analysis. Yale University and Macquarie University: Australia. Center Discussion Paper No. 799.

Sukirno, Sadono. 1985. Ekonomi Pembangunan: Proses, Masalah dan Dasar Kebijaksanaan. Jakarta: LPFE UI.

Tambunan, Tulus. 2006. Iklim Investasi di Indonesia: Masalah, Tantangan dan Potensi. Jurnal Bisnis dan Ekonomi Politik. Vol. 7. No. 2: p.5-27.

Todaro, Michael P and Stephen C. Smith. 2003. Economic Development, eighth edition. Addison Wesley Pearson Education Limited: United Kingdom. 
Verma, R and E. J Wilson. 2005. A Multivariate Analysis of Savings, Investment and Growth in India. University of Wollongong. Economics Working Paper Series. WP-24. http://www.uow.edu.au/commerce/econ/wpapers.html.

Wijaya, Faried. 1992. Ekonomika Pertumbuhan dan Internasional, edisi pertama. Yogyakarta: BPFE. 